\title{
DETERMINANTS OF POVERTY IN PAKISTAN
}

\author{
Asghar Ali* \& Sajjad Ali $\dagger$
}

\begin{abstract}
This research is about the impact of determinants of poverty in Pakistan. In this paper five independent macroeconomics variables that are government expenditure, budget deficit, unemployment rate, exchange rate and inflation rate are studied. In methodology, we have applied the Ordinary Least Squares (OLS) method. The time series data is used which consist of 19 observation that is 1995 to 2013 which we collect from different sources such as (WDI) and (The Global Economy.Com). Through this model we inquired the effect of Government Expenditure, Budget Deficit, Unemployment Rate, Exchange Rate, and Inflation Rate on poverty in Pakistan. Government expenditure and budget deficit have inverse relationship while unemployment has a direct relationship with poverty in Pakistan. Furthermore in this model we seek the impact of inflation rate and exchange rate which help us show negative relationship with poverty while inflation has also a direct relationship with it. In this thesis all of the five variables have been used with three out of five have negative and the other two have a positive relationship with poverty. Theoretically we have proved the relationship of these macroeconomics variables with the help of reference articles by collecting historical data according to Pakistan perspective on these variables.
\end{abstract}

Keywords:Poverty; government, budget deficit, unemployment rate, and inflation rate; Pakistan

\footnotetext{
* MS student, Faculty of Business \& Economics Department of Economics, AWKUM-KP.

$\dagger$ BS Economics, Govt. PG Jehanzeb College Swat KPK Pakistan.
} 


\section{Introduction}

Poverty is the key problem of the developing nations. In the global scenario, in the last 30 year economic growth has occurred along with the increase in portion of poor people increased. In 1960 income of $20 \%$ of the richest countries was 30 times more than $20 \%$ of the poorest people of the countries. International Labour Organization define poverty as a condition in which a person is not capable to achieve his basics needs. Poverty is a crucial immoral or evil which describe certain percentage of the people that are not capable to get minimum standard of living. The poor people struggle their full life to achieve their basic needs while rich people use luxury goods and satisfy their wants and needs. On the other hand inequality occur in the society and the poor people suffers. The poor people have no power for their right as the rich and upper class people destroy their rights for their own enjoyment or benefits. So many international organizations like United Nation or the World Bank struggle for poverty reduction. The World Bank statistics shows that 1.29 billion people are living in absolute poverty in 2009. Nearly 650 million people live in India, Pakistan, China, Bangladesh and Africa at the highest rate is $47 \%$ which occur below the absolute poverty.

Darcon (2001) examines the determinants of changes in poverty and growth. His experimental outcome shows that whole consumption grow and poverty diminishes significantly during the time beneath deliberation. He says that the key point arising from income deviation are comparative price deviations. Subsequently deviations in the outcomes to location, land, human capital and labor. Krishnan and Dercon (1998) evaluate different poverty levels in 1989 and 1995 and also test the heftiness of measured variation in the problem of sets of poverty lines and effect of ambiguity of the rate of inflation measurement. They originate that poverty decayed between 1989 and 1994 nevertheless continued almost unaffected among 1989 and 1994 and that household with considerable physical capital and human capital and improved entrance to towns and roads both have weak poverty levels and are further expected to achieve best of over period. They also found that human capital entrance to towns and roads decrease the variation in poverty throughout the period. They used micro level statistics from towns in rural Ethiopia.

Poverty is a condition in which people's lack of household water and basic needs or lack resources, its compulsory to be achieve and consume a certain minimum basket of goods. The basket goods mean clothing, food, housing and another essential basic needs. Now-a-day's poverty is a global 
menace which describe and presents scarcity in well being of people. It exists where people are not able to satisfy their basic needs which are important for survival.

In 2006, 23.9 percent of the people lived below the poverty line which was calculated by United Nation Development Program (UNDP). At that time the government calculated the poverty line 25.7 percent. The 20142015 Economic Survey of Pakistan reported that $34 \%$ of the people are living below the food poverty line. In Pakistan a huge share of the household budget is consumed on food. Half of the household consumption expenditure is used to meet the nourishment requirement of the household at national level.

Poverty has many forms but two are most extreme type are Relative poverty in which a person is not able to continue lowest level of living specific society. The low level income is determined by government as place where that person lives. The second type is Absolute poverty, it refers to the scarcity of basic human needs which commonly includes food, water, clothes, shelter, health and education. Simply it means that people who can't earn two dollar, they are consider and measured in absolute poverty. The study examining the determinants of poverty in Pakistan, our result is that average $40 \%$ of households are poor at national level.

\section{Research Question}

Whether Government Expenditure, Exchange Rate, Unemployment Rate, Budget Deficit, Inflation Rate, significantly determine the poverty of Pakistan or not?

\section{Objective of the Study}

This study is;

i. To explore the relationship of poverty with its five determinants i.e. Govt Expenditure, Exchange Rate, Unemployment Rate, Budget Deficit and Inflation Rate.

ii. To give some suggestion to government of Pakistan for the reduction of poverty in Pakistan

\section{Hypothesis to be tested}

We made two hypotheses for a model and to take decision regarding the acceptance or rejection for null hypothesis 
$\mathbf{H}_{\mathbf{0}}$ : There is no relationship between Poverty, Government Expenditure, Exchange Rate, Unemployment Rate, Budget Deficit and Inflation Rate.

$\mathbf{H}_{1}$ : There is a relationship between Poverty, Government expenditure, Exchange Rate, Unemployment Rate, Budget Deficit and Inflation Rate.

\section{Literature Review}

Huma and Imran, (2014) investigated the determinants of poverty in Pakistan and showed the impact of macroeconomic variable on poverty. In their research article, they took five variable and used two model specification and run the methodology ordinary least squares. His study has cast off the effect of budget deficit government expenditure and unemployment on poverty in Pakistan. While he showed the relationship between unemployment and poverty is positive and the Govt expenditure and budget deficit shows negative relationship with poverty, so in the second model he investigated the effects of exchange rate and inflation rate on poverty. The exchange rate shows positive relation with poverty and the inflation rate shows positive relationship with poverty. He described the relationship of these variable are statistically significant and proved the theoretical perception.

Danish (2013) examines "the determinants of poverty in Pakistan" in his study. He stated poverty dynamics and their determinants in the context of Pakistan. He examined the relationship between poverty and its five major determinants - poor governance, corruption, health and inequality

Javid et al (2012) showed the determinants of poverty in Pakistan and the effect of inflation on poverty. He collected the time series data from 1973-2010 and used the ARDL technique on this data. He showed the result at the inflation impacts are positive and significant. He showed that inflation has a powerful and statistically significant impact on poverty declining.

Sikandar and Rizvi (2013) show in their research paper that effect of agriculture growth, trade directness and employment, poverty reduction collected the time series data for 1980-2010. He applied on integration and error correlation model, as evidence of his paper saying that all variables have a powerful and statistical impact on poverty reduction.

The Government expenditure has positive effect on poverty but higher Govt expenditure effects budget deficit, which bring inflation budget deficit occur in many developing countries. It causes unemployment and stop private investment for a long run in country. Fan and Rao (2003) show the impact of govt expenditures on 45 under developed countries to show different kind of govt expenditures and different effects on economic growth 
but spending on agriculture sector to recover crops growth in economy. The big portion of people in developing countries and rural area people have only one source of receiving that is agriculture so it will increase output and decrease the poverty of rural area.

Mahmood and Chaudhry (2012) find the effect of FDI on poverty decline. He collected the time series data from 1973 to 2003. The ARDL and Error correlation models are used and got the results in short run and long run interactions. The study describes that the variables are totally significant and have negative effect on poverty.

Egbe and Clement (2011) in their thesis "The Influence of Macroeconomic Policies and Programs on Poverty Problem" describe the effect of some macroeconomic policies on poverty in Nigeria during 19902002. They showed the causes of poverty in the state instead of the measure taken by the govt to alleviate the impact of poverty. To analyze the data they ran regression equation models on poverty and GDP and describe the policies and programs and showed that macroeconomic variables have no impact on the skyward trends of poverty in the state.

Hassan, Chaudhry and Malik (2009) examine "the Effect of Socio Economic and Demographic Variables on Poverty". A case study analyzed the impact of socio economic and demographic variables on poverty. They used primary data and poverty profile and analysed by using econometric approach in his conclusion. They showed that dependency of household, landholding, house hold size, number of livestock and landholdings have impact on the occurrence on poverty. They suggest that there would be need to encourage the socio economic factors and land should be Selected to landless households.

Jamal (2006) studied the relationship between inequality, growth and poverty for Pakistan on macro level. He determined that there was positive relationship between the income inequality, GDP per capita and wage gap in different sectors of economy and the terms of trade corrupt result on the inequality. He also examined that low level of income inequality helped in poverty alleviation and explained steps to control and decrease inequality and poverty. Iqbal and Zahid (1998) showed the effects of budget deficit and cast off in their study. A negative correlation exist between budget deficit and productivity. He showed in his study that increasing taxes in the economy effect the govt expenditure and decrease the private investment.

Mahmood and Sadiq (2010) determine the high budget deficit of any government. They have two options to cover their budget deficit - one is borrowing from external sources which improve the exchange rate and pay back the amount of interest in foreign currency. The demand for foreign 
currency increases and devalue the local currency and also government increases taxes which reduce the investment by people of the country. The situation happens in Pakistan economy when export decrease the currency devalue. The second option is that government can borrow internally from other countries so its interest rate is very expensive because the exchange rate is the element of interest so it will increase interest rate in economy. People will start saving because of high interest, its impact which reduces purchasing power and circulation of money in country.

\section{Data Variable and Methodology}

\section{Data Variable}

The responsible factor of poverty plays main role in the reduction of poverty in developing countries like Pakistan. In this thesis we used five variables to check their effect on poverty in Pakistan. For these variable, the data is collected from (WDI) and Economic Survey of Pakistan. The time series data is used which consists of 19 observation from 1995 to 2013. The variables and their measurements are given below:

1. Poverty is measured in head count ratio (POV)

2. Government Expenditure is measured in percentage of GDP.

3. Budget Deficit is calculated in millions of rupees.

4. Unemployment rate

5. Inflation Rate.

6. Exchange rate in term of US dollar

\section{Methodology}

This study will use the ordinary Least Square (OLS) method to investigate the degree of relationship as well as path of relationship (positive or negative) for these variable.

\section{Economic Theory or Estimated Sign}

i. Government Expenditure is measured in percentage of GDP. The economic theory suggest that government expenditure and poverty for expected sign is negative because increase in spending by agriculture side improve the crops growth in developing countries as most of the population reside in rural area whose source of earning is agriculture. Poverty will decrease as a result. 
ii. Budget Deficit is calculated in million (RS). The economic theory suggest that between budget deficit and poverty, there is negative correlation because increase in taxes and expenditure decreases private investment. When spendings are reduce as a result poverty increases.

iii. Unemployment Rate that calculated sign is increase in unemployment as result it will increase poverty so the economic theory suggest a positive sign is calculated for co efficient

iv. Inflation is also the main problem to increase poverty so when inflation increase in a country, it leads to decrease in the consumption of the people when consumption decrease it decrease the aggregate demand means that standard of living of people is low. Poverty increases so the economic theory suggests that positive sign is expected for inflation and poverty

v. Exchange Rate The economic theory suggest that exchange rate and poverty have negative correlation because of variation in exchange rate indirectly effect poverty.

\section{Data and its Source}

For our thesis, the data is collected from secondary sources such as Economic Survey of Pakistan, (WDI), Hand book of Statistics on Pakistan Economy and the GlobalEconomy.com. We have used time series data by year wise from 1995 to 2014 and a multiple regression model.

\section{Econometric Model}

In this study we will use multiple regression approaches to explore the relationship between the dependent and independent variables. Through OLS approach we will estimate the co efficient of the independent variable.

$$
P O V=f(G E, B D, U N E, I N F R, E x R)
$$

In the above model:

$\mathrm{POV}=$ Poverty is measured in head count ratio $(\mathrm{POV}$

$\mathrm{GE}=$ Government expenditure is measured in percentage of GDP

$\mathrm{BD}=$ Budget deficit Budget Deficit is calculated in millions of rupees

$\mathrm{UNE}=$ unemployment rate

INFR = Inflation rate

ExR $=$ Exchange rate in term of US dollar 
Now the econometrics model are below:

$$
P O V=\beta_{0}+\beta_{1} B D+\beta_{3} U N E R+\beta_{4} I N F R+\beta_{5} E x R+E
$$

The above econometric model represent the relationship between dependent and independent variables $\beta_{0}$ stand for constant term, $\beta_{1}$ represents the regression coefficient of Government Expenditures. Similarly $\beta_{2}$ for Budget Deficit and $\beta_{3}$ for Unemployment Rate while $\beta_{4}$ represents coefficient of Inflation Rate and $\beta_{5}$ represent the coefficient of Exchange Rate.

\section{Result and Discussion}

This paper investigate the relationship between variables and its impact on poverty in Pakistan. So we explore the determinants that are Government Expenditure, which is measured in percentage of GDP, Budget Deficit which is calculated in millions of rupees, Inflation Rate, Exchange Rate and Unemployment Rate. In this study we had to make a decisions that there is positive relation or negative relation with poverty. If there is positive relation then they are significant or insignificant so, we accept the null hypothesis and reject alternative hypothesis on the basis of econometrics model.

\section{Descriptive Statistics of Relevant Variables}

The descriptive statistics help to give us the analysis of data signify or summarize data in a meaningful way or a set of brief statistics that signify measure of significant tendency include mean, median, standard deviation, minimum, maximum variables, kurtosis and skeweness. The descriptive statistics are very essential because if we simply presented a time series data it would be difficult to visualize what data is shown more. A lot of it enables us to represent the data in a more meaningful way which is shown in much simpler interpretation of the data. Table of descriptive statistics as shown below table 1 . 


\section{Table 1: Descriptive Statistics}

\begin{tabular}{|l|c|c|c|c|c|c|}
\hline Sample: 1995-2013 & & & & & \\
\hline & POV & GE & BD & UNER & INFR & EXR \\
\hline & & & & & & \\
\hline Mean & 32.39526 & 14.36737 & 1703.750 & 5.984211 & 8.431579 & 62.89272 \\
\hline Median & 30.80000 & 13.39000 & 1461.982 & 5.700000 & 7.700000 & 59.72380 \\
\hline Maximum & 62.60000 & 25.46000 & 9476.834 & 7.800000 & 20.30000 & 96.72720 \\
\hline Minimum & 17.20000 & 8.390000 & -3391.525 & 4.900000 & 2.900000 & 31.64270 \\
\hline Std. Dev. & 12.27511 & 4.877578 & 2895.167 & 1.084365 & 4.518979 & 19.29669 \\
\hline Skewness & 0.967465 & 0.911603 & 0.640891 & 0.542987 & 0.870408 & 0.342737 \\
\hline Kurtosis & 3.489656 & 2.838806 & 4.302083 & 1.646980 & 3.516178 & 2.218415 \\
\hline & & & & & & \\
\hline Jarque-Bera & 3.153775 & 2.652132 & 2.642888 & 2.382917 & 2.610028 & 0.855593 \\
\hline Probability & 0.206617 & 0.265520 & 0.266750 & 0.303778 & 0.271169 & 0.651944 \\
\hline \multicolumn{2}{|c|}{} & & & & & \\
\hline Sum & 615.5100 & 272.9800 & 32371.25 & 113.7000 & 160.2000 & 1194.962 \\
\hline Sum Sq. Dev. & 2712.208 & 428.2338 & $1.51 \mathrm{E}+08$ & 21.16526 & 367.5811 & 6702.517 \\
\hline Observations & 19 & 19 & 19 & 19 & 19 & 19 \\
\hline
\end{tabular}

The descriptive Table 2 shows the different statistics of variable which we used in our regression analysis. It represents overall picture of the data. Descriptive statistics are mentioned as the mean, median, maximum and minimum for finding the center of the data and extremes of the data, standard deviation is given for the measure of dispersion, skeweness for the distribution of the figures around mean from left and right. Finally kurtosis shows peakedness or probability of values around the mean.

\section{Correlation Table}

Correlation is a statistical technique/method that shows whether and how strongly pairs of variables relate or it represent standardize measure, bounded between -1 and +1 of the strength association between two variable. The correlation may be perfect positive or perfect negative correlated as shown below Table 2 . 
Table 2 : Correlation Results

\begin{tabular}{|l|c|c|c|c|c|c|}
\hline & POV & GE & BD & UNER & INFR & EXR \\
\hline POV & 1.000000 & -0.711395 & -0.081484 & 0.123545 & 0.021639 & -0.897499 \\
\hline GE & -0.711395 & 1.000000 & 0.284599 & -0.538844 & 0.271260 & 0.903785 \\
\hline BD & -0.081484 & 0.284599 & 1.000000 & -0.649995 & 0.716510 & 0.078804 \\
\hline UNER & 0.123545 & -0.538844 & -0.649995 & 1.000000 & -0.642380 & -0.313221 \\
\hline INFR & 0.021639 & 0.271260 & 0.716510 & -0.642380 & 1.000000 & 0.119759 \\
\hline EXR & -0.897499 & 0.903785 & 0.078804 & -0.313221 & 0.119759 & 1.000000 \\
\hline
\end{tabular}

The above table 2 presents correlation coefficient of poverty with determinants that is independent variable. So keeping the other variables constant in the above figure, the Government expenditure is negatively correlated with poverty, its coefficient is -0.711395 . The other variable Budget Deficit is negatively correlated with poverty as shown in the above table with value of -0.081484 . While the unemployment has positive relation with poverty 0.123535 coefficient. The exchange rate and inflation rate are in positive relationship so all the determinants i.e. is independent variables which shows the effect and relationship with poverty in the above correlation table.

\section{Regression Table}

The regression analysis shows the dependency of one variable on the other variables. There are two basics types of regression linear regression and multiple regression but here we used multiple regression which refers to the relationship between more than two variables.

\section{Table 3: Regression Results}

Dependent Variable: POVERTY HEAD COUNT RATIO

Method: Least Squares

Included Observations: 19

\begin{tabular}{|l|c|c|c|c|}
\hline Variable & Coefficient & Std. Error & t-Statistic & Prob. \\
\hline C & 73.26481 & 12.11020 & 6.049845 & 0.0000 \\
\hline GE & 1.607359 & 0.608406 & 2.641921 & 0.0203 \\
\hline BD & -0.001598 & 0.000527 & -3.030024 & 0.0097 \\
\hline UNER & -1.088057 & 1.501536 & -0.724629 & 0.4815 \\
\hline INFR & 0.643042 & 0.328738 & 1.956093 & 0.0723 \\
\hline EXR & -0.956413 & 0.137441 & -6.958689 & 0.0000 \\
\hline R-squared & 0.918981 & Adjusted R-squared & 0.887820 \\
\hline F-statistic & 29.49121 & \multicolumn{5}{|l}{ Durbin-Watson stat } & 2.013611 \\
\hline Prob(F-statistic) & 0.000001 & \multicolumn{5}{|l}{} \\
\hline
\end{tabular}


By applying Ordinary Least Square (OLS) method the regression model result shows the connection of different independent variables with dependent variable that is poverty. So in the above table the coefficient of Government expenditure that is (GE) displays negative relationship with poverty and P-value is 0.0203 so it has significant effect on coefficient. The relationship between poverty and Budget deficit also has a negative relation and its P-value .0 .0097 so its effect on coefficient is significant with poverty so we find that as government expenditure and budget deficit high so it decrease poverty. The relationship between unemployment and poverty is positive but its effect on the coefficient is insignificant because its P-value is 0.4815 . Its greater than the value of $5 \%$ significant level so its effect on coefficient is insignificant but its relation is positive so increase in unemployment increases poverty. On the other hand exchange rate and poverty has a negative relation because increase in exchange rate as a result of currency depreciation cause poverty so it has a negative relation and significant effect. It's P-value 0.0000 which is less than the significant level of coefficient as shown in the above table while the inflation and the poverty show a positive relation with $\mathrm{P}$-value of .0 .0723 which is less than significant level so its effect is significant on coefficient and positive relationship because of increase in inflation caused by poverty. Here the $\mathrm{R}-$ square $\mathrm{R}^{2}=0.91$, it means that $91 \%$ variation are due to the explanatory variable and the other $9 \%$ occurred due to the error term with the basis of Fstatistics the overall model is significant. Its F- statistics value is greater than 2. Here the F-statistics is 29.49 and P-value is 0.000001 its means that the model is significant. Here the Durbin Watson value is 2.01 so it means it has no auto correlation. When the value is exact 2 its means there is no auto correlation and when its less than 2 it means negative autocorrelation. Through this result we find that all determinants have a relationship with poverty so we reject the null hypothesis $\mathrm{H}_{0}$ and accept the alternative hypothesis $\mathrm{H}_{1}$ because all the relationships fall in the $\mathrm{H}_{1}$ alternative Hypothesis. 
Fig. 1: Graphical Representation of Data

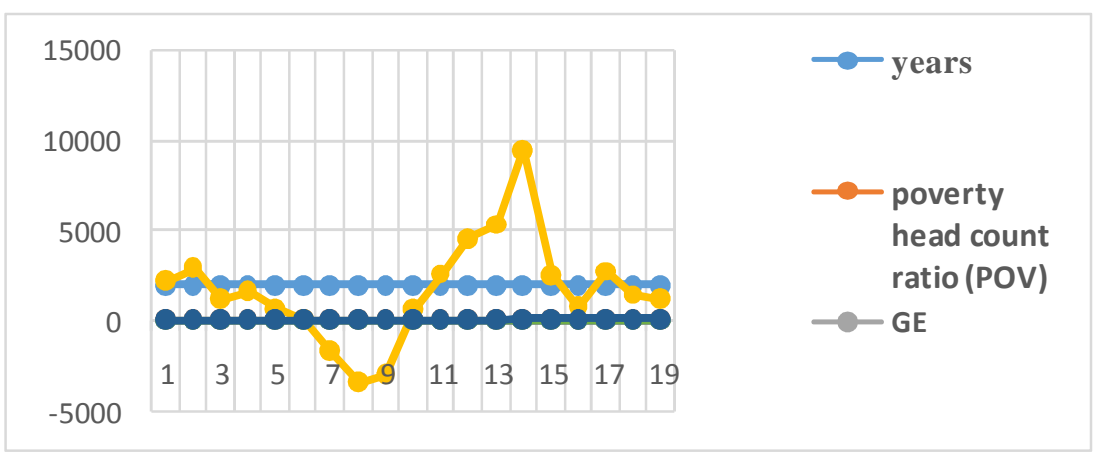

Source of data: (WDI and the Global economy.com from 1995 -2013)

Figure 1 show the relationship between dependent and independent variables from 1995 to 2013 . The dependent variable is poverty which is measure in head count ratio and the other independent variable is Govt expenditure which is measured in percentage of GDP (GE). Budget deficit is measured in millions of pkr (BD), Unemployment rate(UNER), Inflation rate (INFR) and Exchange rate (ExR). In this thesis all of the five variables have been used. Three out of these five have negative and the other two have a positive relationship with poverty. Government expenditure, budget deficit and exchange rate have a negative and significant relation while unemployment and inflation have a positive correlation with poverty. So when the govt adopt fiscal policy and increase government spending either through subsidies or through development expenditure like roads, schools and hospitals then the employment increase an economy as impact is poverty reduced. The budget deficit occur when the govt. expenditure exceeds govt. revenue then the budget deficit happen in economy. For this problem the govt. borrows from external and internal sources to cover their own expenditure. If the budget deficit occur due to productive work like social welfare and subsidies then its reduce the poverty. So we found that all of the independent variables which are used in regression model have strong impact on poverty.

\section{Conclusion and Recommendation}

Through this research we found out the determinants of poverty in case of Pakistan. Nowadays, poverty is the main problem in every country. The key objective of the study was find those factors which determine poverty in 
Pakistan and to investigate their effect on poverty whether positive or negative by seeing the result. After we arise to see about the process of idea for making good policies concerning the determinants of poverty.

The data is collected from secondary sources such as development indicator (WDI) and (The Global Economy.com). The methodology we used is the OLS estimation method. In this study we have used five variables which are government expenditure, budget deficit, unemployment rate, exchange rate and inflation rate which determine poverty and to finding the relation between macroeconomics variables and poverty. In all five variables, we found the relationship between poverty and government expenditure, budget deficit have negative or inverse relation with poverty while unemployment have positive relation with poverty. Because the fiscal policies have a direct effect on government expenditure when the spending of government increase through subsidies and through development spending on road schools and hospital, the employment increases in economy and income of the people and spending of people rises as result poverty reduced. In other words if the government spending increase than government revenue in the specific year it represent a fiscal deficit. The budget deficit and poverty have negative relationship and significant relation in Pakistan. It means govt. is either involved in development projects or subsidies due to which unemployment decreases. It leads to poverty reduction due to subsidized prices of goods, decreasing poverty. It also declines because the inflation and poverty have positive relationship. If the budget deficit occurs due to productive work like social welfare then it reduces poverty, otherwise unproductive sector such as defense expenditure cannot help in reducing the poverty.

The exchange rate and poverty in negative relationship and significantly impact on the model coefficient. Falling of currency in term of other currency may be good for those people who earn foreign exchange but for the whole economy, its effect is increasing inflation. When inflation occurs due to currency devaluation the firms buy input at high cost from other countries so prices of the goods increase and poverty increases. The exchange rate is considered a variable which effect the poverty while inflation is another factor which increases poverty. When the general price level increases the people purchasing power or consumption decrease which lead to decrease in aggregate demand and also decrease in standard of living of the people. As result it increases poverty always positive relationship with poverty. The govt. needs to make strong policies to reduce poverty and do productive work which can help us to eliminate poverty. The govt. needs to improve the agriculture sector and productivity because large population of 
the country lives in rural area and its earns from agriculture sector. The govt. should introduce transparency and provide better health facilities and provide facilities to poor people through social welfare and impose taxes on rich people and help the poor people. The govt. also needs to provide job opportunities and introduce micro financing in rural area and provide free education and help poor people

The fact is there are a lot of problem which effect the poverty but we used time series data and took five variables and ran multiple regression models which showed 90\% variation in poverty in Pakistan. So in the model unemployment is insignificant and it has no effect on poverty but with other variables it lead to a significant effect on poverty.

\section{References}

Azam, M., Haseeb, M., \& Samsudin, S. (2016). The impact of foreign remittances on poverty alleviation: global evidence. Economics and Sociology, 9(1): 264-281.

Azam, M. (2011). Causes and measurement of poverty reduction in Pakistan. Interdisciplinary Journal of Contemporary Research in Business. 2 (11): 76-83.

Anwar. T, Ali. S and Qureshi. S.K. (2002)," trend in absolute poverty in Pakistan: 1990-91 and 2001. The Pakistan development review. 41:4 part II (winter 2002) pp, 859-878.

Batool. S. Mainkahil. (2013)." Causes and Consequences in Pakistan. Journal managerial of economics. Qurtaba university of pakistan. Vol 2. Number 1.

Chudhry. I. Sharif. (2009)." Poverty Alleviation in Southern Punjab (Pakistan): An Empirical Evidence From the project Area of Asian Development Bank. international research journal of Finance and Economics -Issue 23 (2009)

Cheema. A.R. (2014)." Poverty and its determinants in Pakistan: Evidence from Pslm 2010-11. Journal of poverty and development. Vol.5 2014

Dercon, (2001); economic reform, the poor and growth: evidence from rural Ethiopia,........series paper 2001-08african economies, oxford.

Haseeb, M., N.H. Hartani, N.A.A. Bakar, Azam M. \& S. Hassan, (2014). Exports, foreign direct investment and economic growth: Empirical evidence from Malaysia (1971-2013). American Journal of Applied Sciences, 11: 1010-1015. 
Irfan. M. (2011). "Remittances and poverty linkages in Pakistan: evidence and some suggestion for further analysis. Pakistan institute development economics. Vol. 5, NO.1 pp, 34.

Javid et. al. (2012) the determinants of poverty and effects of inflation in Pakistan;...........pslm 2010-11 journal of poverty and development. Vol, 5, 2014.

Krishnan and Dercon (1996); income portfolio in rural Tanzania and Ethiopia:.........Journal Of development studies (6) 32: 850-875.

M Danish (2001): determinants of poverty in Pakistan;...........the Pakistan development review, 42; 5 pp, 859-878

Mahmood and Chaudrey (2012); the effect of FDI on poverty; .....the project area of Asian development bank. International journal of finance and economics- issue23 (2009)

Muhammad, A., \& Khan A.Q., (2017). Growth-Corruption-Health Triaca and environmental degradation: Empirical evidence from Indonesia, Malaysia and Thailand. Environmental Science and Pollution Research, 24 (2017), 16407-16417.

Majeed. M.T. and Malik. M.N. (2014).” Determinants of household poverty: empirical evidence from Pakistan. Quaid-i-Azam university, Islamabad, Pakistan

Pervez. S. and Rizvi. S.B.H. (2014),"Determinants of poverty in case of Pakistan". International research journal. Vo. 5(6) pp. 192-201, July, 2014.

Sikender and Rizvi (2013); the effect of agriculture growth trade directness and employment poverty reduction:..... J Globe. \& Sci. Issues, 1, (March 2014).

Pervez. S. and Rizvi. S.B. Hussain. (2014)."An empirical analysis on determinants of poverty: A co-Integration Analysis. J. Glob. \& Sci. Issues, Vol, Vol 2, Issues 1, (March 2104).

Shoaib. M. Danis. (2013)" Determinants of poverty in Pakistan .University of Gujrat Chakwal and Department of Economics.

Usman, Mubasher." Socio-Economic Determinants of Poverty. A Case of Pakistan. Development and International Relations, Aalborg University, Denmark pp. 7-8.univirsity of Gujrat. Economics department.

Yousaf. H. and Ali. I. (2014). "The determinants of poverty in Pakistan. International journal of economics and empirical research. 2(5), 191202. 